\title{
STRATEGI CAMP DALAM NOVEL HIDING MY CANDY KARYA LADY CHABLIS
}

\author{
Sri Saraswati \\ Universitas Gadjah Mada \\ Email: sarasvathi713@gmail.com
}

\begin{abstract}
Abstrak
Penelitian ini dilakukan untuk mengulik bentuk-bentuk strategi Camp dan tujuan penerapannya melalui novel Hiding My Candy karya Lady Chablis. Hiding My Candy merupakan sebuah novel yang merepresentasikan upaya kebertahanan transgender yang dilakukan oleh tokoh The Doll. Adapun pendekatan yang akan digunakan dalam penelitian ini adalah teori Camp oleh Moe Meyer. Dalam buku the Politics and Poetics of Camp, Moe Meyer mendefinisikan istilah Camp sebagai total keseluruhan praktik dan strategi untuk menunjukkan identitas queer kaum marjinal, dalam hal ini transgender, kepada masyarakat (visibilitas sosial). Lazimnya, masyarakat heteronormatif menganggap transgender sebagai liyan sehingga keberadaan mereka seringkali terpinggirkan. Maka, tujuan dari penerapan strategi Camp adalah untuk menjamin kebertahanan kaum transgender dalam masyarakat. Muatan kritik terhadap heteronormativitas juga tampak nyata dalam penerapan strategi Camp. Sasaran kritik tersebut adalah pemapanan konstruksi gender normatif serta eksklusifitas kaum heteroseksual yang menjadikan kaum marginal seperti transgender tersisihkan. Berdasarkan hasil penelitian ditemukan bahwa bentuk-bentuk strategi Camp dapat dirinci sebagai berikut; strategi parodi Camp, strategi humor Camp, strategy of posing (kostum, gestur dan gaya bicara) serta strategi hidup dalam pertunjukkan. Penerapan strategi Camp tersebut ditujukan sebagai upaya untuk meraih kebertahanan transgender. Selanjutnya, kebertahanan transgender dapat dicerminkan melalui visibilitas sosial, terbentuknya wacana normalitas alternatif dan pemberdayaan transgender.
\end{abstract}

Kata kunci: strategi Camp, transgender, kebertahanan transgender, social visibility, heteronormativitas.

\begin{abstract}
This study aims at discussing about the forms of Camp strategies as well as elaborating the purpose of its application in Lady Chablis' Hiding My Candy. Hiding My Candy tells a story of a transgender name The Doll who fights for her survival among patriarchal community. To answer the objectives of the research, Moe Meyer's Camp theory will be applied. In the book of the Politics and Poetics of Camp, Meyer defines Camp as the total body of performative practices and strategies used to enact a queer identity, with enactment defined as the production of social visibility. The emergence of Camp as a survival strategy appears due to the challenge of transgender discrimination resulted by heteronormativity restraint. The study result shows that transgender survival can be divided into three aspects i.e. social visibility, alternative normative and transgender empowerment. Those transgender survival's aspects can be achieved by applying the Camp strategies. Those strategies include parody Camp strategy, bumor Camp strategy, strategy of posing (costume, gesture and speech act) and strategy of life in performance.
\end{abstract}

Keywords: Camp strategy, transgender, transgender survival, social visibility, heteronormativity

\section{Pendahuluan}

Transgender male to female seringkali dicitrakan negatif dalam masyarakat patriarki. Mereka dianggap sebagai figur yang menyimpang karena ketidakmampuan untuk menyesuaikan identitas gender dengan jenis kelamin bawaan mereka. Oleh karena penyimpangan itu, mereka kemudian dianggap sebagai other dan seringkali mendapatkan perlakuan yang tidak adil seperti pelanggaran
HAM dan diskriminasi. Ketidakberpihakan kaum heteronormatif terhadap transgender itu digambarkan dengan jelas dalam narasi beberapa novel bertema transgender. Novelnovel seperti Almost Perfect karya Delacorte, Embrace My Reflection karya T.A. Chase, A Rose is A Rose karya Jet Mykels dan Dress to Thrill karya Kimberly Gardner menarasikan derita transgender yang mengalami diskriminasi karena 'ketidaknormalan' mereka. 


\section{Jurnal Poetika Vol. IV No. 1, Juli 2016}

Representasi diskriminasi dan pelabelan negatif yang menimpa para transgender dalam novel-novel di atas secara umum disebabkan oleh pasifnya para tokoh transgender dalam menghadapi berbagai hinaan, cacian dan bahkan kekerasan fisik. Kepasrahan tersebut menjadikan mereka sebagai sasaran empuk segala serangan kebencian dan stereotip negatif.

Di Indonesia, kasus diskriminasi terhadap transgender sempat tercatat dalam sebuah studi kasus yang dilakukan oleh Lembaga Bantuan Hukum Arus Pelangi pada tahun 2008. Dalam buku yang mereka keluarkan tercatat beberapa nama transgender yang mengalami kekerasan fisik, pelanggaran HAM dan bahkan menjadi korban pembunuhan karena identitas mereka yang dianggap berbeda. Kasus-kasus diskriminasi terhadap kaum transgender itu kebanyakan mengambang atau mentah dalam peradilan karena para korban takut memperpanjang masalah. (Arianto dan Triawan, 2008).

Dalam dunia hiburan di Indonesia pun, kehadiran transgender lazimnya masih dicitrakan sebagai obyek penderita dan bahan tertawaan. Udasmoro menyatakan bahwa segregasi terhadap transgender dibentuk secara sosial, yakni sebagai kelompok yang marjinal. Mereka seakan menjadi sentral, tetapi sebetulnya justru identitas mereka adalah periferi, yakni sebagai guyonan saja dalam masyarakat (Udasmoro, 2015: 6).

Kasus diskriminasi terhadap transgender pun terjadi di Amerika. Memang, seiring berjalannya waktu, jaminan terhadap hak transgender (LGBT rights) termasuk hak berkeluarga, menikah dan hukum anti diskriminasi telah disahkan di Amerika sejak sekitar tahun 2003. Undang-undang mengenai pernikahan sesama jenis, bahkan telah disahkan di seluruh negara bagian Amerika pada 26 Juni 2015 (Chapell: 2015). Namun pada praktiknya, diskriminasi terhadap transgender masih terus terdengar. Dalam hal ini, Wilson menyatakan bahwa seperti kaum gay 30 tahun yang lalu, transgender male to female (waria) dilaporkan mengalami stigma, diskriminasi dan kekerasan dengan frekuensi yang cukup tinggi dikarenakan keengganan mereka untuk mematuhi norma gender yang telah disepakati (Wilson, 2008 : 1). Berbagai ulasan mengenai kasus diskriminasi terhadap transgender baik dalam dunia nyata maupun sastra di atas menunjukkan bahwa kaum transgender masih terkungkung dalam bayang-bayang kekangan heteronormativitas sehingga perjuangan untuk meraih kebertahanan transgender perlu dilakukan.

Lady Chablis merupakan pengarang transgender yang mencoba mengubah citra negatif mengenai transgender dengan menyelipkan fitur kebertahanan transgender dalam novelnya yang berjudul Hiding My Candy. Novel Hiding My Candy merupakan novel semi autobiografi yang digunakan pengarang untuk menceritakan kembali bagaimana ia. seorang transgender Male to Female berkulit hitam mampu bertahan dalam masyarakat dengan cara mengupayakan berbagai strategi bertahan transgender (Camp). Lady Chablis merepresentasikan strategi Camp tersebut melalui tokoh The Doll.

Menurut Moe Meyer dalam bukunya The Politics and Poetics of Camp, strategi Camp didefinisikan sebagai keseluruhan praktik dan strategi performatif yang digunakan oleh kaum marjinal, dalam hal ini transgender untuk menampilkan identitas queer. Strategi penampilan identitas queer itu ditujukan agar ia terlihat oleh masyarakat sehingga mampu bertahan dalam kekangan kaum dominan (heteroseksual). Meyer menyatakan bahwa "Camp adalah keseluruhan praktik dan strategi performatif yangdigunakan untuk menampilkan identitas queer, yang dipertunjukkan untuk memproduksi social visibility (Meyer, 1994:4). Dari pernyataan itu jelas bahwa Camp adalah strategi yang dilakukan oleh kaum marjinal, dalam hal ini transgender untuk mengupayakan visibilitas sosial demi kebertahanan mereka dalam masyarakat normatif.

Penelitian ini dilakukan dengan tujuan untuk mengulik bentuk-bentuk strategi Camp yang direpresentasikan pengarang melalui 


\section{Jurnal Poetika Vol. IV No. 1, Juli 2016}

tokoh The Doll dalam novel Hiding My Candy. Selain itu, tujuan penerapan strategi Camp juga akan coba diuraikan lebih lanjut.

Untuk menjawab rumusan masalah dalam penelitian, aplikasi teori Camp yang juga merupakan bagian dari teori Queer akan digunakan dalam penelitian ini. Queer menyatakan bahwa seksualitas dan identitas gender individu bersifat cair, dan mempunyai kemungkinan pilihan yang cukup beragam. Dari pernyataan tersebut, cakupan teori queer menjadi semakin luas. Maka kaum gay, camp, drag, butch lesbian, femme lesbian juga merupakan isu yang dibicarakan dalam teori queer.Meyer menyatakan bahwa queer tidak terbatas hanya mengindikasikan seks biologis atau gender dari seorang subjek belaka. Istilah ini lebih jauh merujuk pada tantangan terhadap pelabelan secara filosofis, terutama kiasan pembedaan pada istilah "homoseksual," dan juga tantangan terhadap kategori pembedaan gender yang dilekatkan pada frasa "gay dan lesbian." (Meyer, 1994: 2).

Sementara itu, istilah Camp muncul pertama kali dalam kamus bahasa slang yang ditulis oleh J. Redding Ware pada tahun 1909 berjudul Passing English of the Victorian Era: A Dictionary of Heterodox English, Slang, and Phrase. Dalam kamus tersebut, Ware mendefinisikan Camp sebagai 'aksi dan gestur dengan penekanan exaggeration (sesuatu yang dilebihlebihkan). Ia menambahkan bahwa istilah Camp kemungkinan besar berasal dari bahasa Perancis, dan biasanya digunakan oleh orangorang yang tersisihkan. Booth menambahkan asal kata Camp dari bahasa Italia dan Perancis campeggiare dan Perancis se camper yang kira-kira dapat diartikan 'menampilkan seseorang dalam mood yang meluap-luap tetapi mempunyai sikap lemah lembut-dengan sisipan unsur teatrikal, jumawa, bergaya dan provokatif. (Booth, 1983:75).

Pada mulanya istilah Camp merupakan istilah slang yang digunakan oleh kaum yang terpinggirkandiera Victoria.Darisegietimologis, Camp adalah kata kerja aktif yang mempunyai kaitan erat dengan aspek pertunjukkan, exaggeration, teatrikal, gaya dan bersifat provokatif. Menurut Fabio Cleto dalam buku Camp: Queer Aesthetic and the Performing Subjects, Camp pertama kali dipakai oleh transvestif bernama Fanny untuk korespondensi dengan rekan sesama transgender. Isherwood dalam novelnya The World In Evening juga mengaitkan Camp dengan queer melalui tokohnya Charles yang diceritakan merupakan seorang biseksual. Dari uraian di atas, jelas terlihat bahwa Camp selalu terkait dan tidak bisa dilepaskan dari queer.

Namun, pada tahun 1964, dalam artikelnya yang berjudul Notes on Camp, seorang akademisi bernama Susan Sontag mencoba mendefinisikan Camp dalam 58 karakteristik. Secara ringkas, ia menganggap Camp sebagai sensibilitas, dangkal, estetis, dan keseriusan yang dipelintir. Moe Meyer dalam bukunya The Politics and Poetics of Camp (1994) mengkritik definisi Camp menurut Sontag. Kesalahan Sontag, menurut Meyer adalah ketika ia menafikan peran homoseksual sebagai kaum marjinal penemu Camp. Hasilnya, Camp tampak seperti tanpa muatan, apolitis, hanya mementingkan gaya dibanding isi, dangkal, dan bersifat mainmain.

Dalam perspektif Meyer, dengan dasar sejarah panjang Camp dan keterkaitannya dengan queer, Camp tidak akan bisa dilepaskan dari penemunya yaitu kaum marjinal (queer) (Meyer, 1994). Maka, sebagai produk kaum marjinal yang dimunculkan oleh kaum homoseksual, Camp pasti berpotensi memuat kritik dan politis di dalamnya. Berangkat dari titik tersebut, wacana yang muncul dari kaum marjinal tentu akan bersifat politis dan mempunyai intensi untuk mengkritik kaum dominan (kulit putih, kaum burjois dan model identitas normatif). Camp bersifat politis; Camp adalah wacana queer; dan khususnya Camp mewujudkan kritik queer terhadap budaya (Meyer, 1994:1).

Selanjutnya, Meyer menyatakan bahwa cara beroperasi Camp dianalogikan seperti jubah gaib, maksudnya Camp dioperasikan secara sembunyi-sembunyi. Strategi Camp 


\section{Jurnal Poetika Vol. IV No. 1, Juli 2016}

tidak dilakukan secara secara terang-terangan, tetapi disamarkan lewat misalnya parodi yang bermuatan penyimpangan, mencemooh diri sendiri, pertunjukkan, humor untuk mengatasi masalah dan strategi dalam bersikap lewat gestur, kostum dan gaya bicara. Beroperasi dari balik jubah gaib, queer mengerti praktik mana saja yang telah dilegitimasi, dan queer secara otomatis tahu praktik yang dilakukannya akan; dan harus diterima. Sebagai produk agensi Queer, tugas Camp adalah menyeleksi dan memilih aspek queer mana saja yang akan ditampilkan ke dalam budaya dominan. (Meyer, 1994: 8-9).

Pendapat Meyer tersebut diaminkan oleh dua akademisi lain yaitu Esther Newton dan Jack Babuscio dalam buku Camp: Queer Aesthetic and the Performing Subjects. Baik Meyer, Newton atau pun Babuscio mendefinisikan Camp sebagai perilaku aktif atau proses dalam bentuk strategi yang dilakukan oleh agen queer (kaum transgender) untuk menampilkan diri ke dalam masyarakat (social visibility). Camp menunjukkan respon kritis dan politis kaum marjinal dalam menghadapi diskriminasi dan peng-'other'-an oleh kaum dominan. Alih-alih pasrah dengan segala cibiran, cemoohan dan pelabelan negatif, kaum transgender justru mentransformasikan segala diskriminasi itu menjadi sebuah keunikan dan 'normalitas' ala mereka.

Dirangkum dari pemikiran Meyer, Newton dan Babuscio, strategi Camp untuk social visibility dilakukan dengan mengupayakan strategi parodi Camp, strategi humor Camp, strategi dalam bersikap melalui gestur, kostum dan gaya bicara serta strategi hidup dalam pertunjukkkan. Parodi Camp merupakan strategi yang menonjolkan aspek tiruan sebagai kritik terhadap heteronormativitas. Parodi Camp bukan merupakan tiruan secara mentahmentah, selalu ada penyimpangan yang ditujukan sebagai kritik di dalamnya. Ketika parodi ditilik sebagai proses, dan bukan sebagai bentuk, maka keterkaitan antara kedua teks akan menjadi indikator hubungan kekuasaan antara agen sosial yang memegang kedua teks tersebut, mana yang 'asli', dan mana yang mempunyai alternatif parodi. (Meyer, 1994 : 9). Sementara itu, strategi humor camp menyajikan sebuah ironi yang berusaha mengangkat prinsip laughter in tears yaitu mencoba memandang permasalahan dari sisi positif dan mencari penghiburan di dalamnya. Dalam strategi humor Camp, agen queer, dalam hal ini transgender mencemooh diri sendiri, menampilkan flaw, ketidaklayakan (incongruity) diri sendiri untuk mengubahnya jadi power. Newton menyatakan bahwa humor Camp adalah 'sistem tawa atas ketidaklayakan posisi seseorang dibanding menangisinya. Jadi, humor tidak menutupinya, tetapi bertransformasi (Newton, 1999: 100).

Selanjutnya, dalam strategy of posing, konsep-konsep exaggeration dan incongruity diangkat melalui gestur, kostum dan gaya bicara yang bersifat satire. Strategi life in performance menonjolkan unsur being what-isnot yang dilakukan oleh agen queer. Mereka selalu memandang segala sesuatu sebagai pertunjukkan, termasuk identitas gender yang dianggap sebagai sesuatu yang dapat dimanipulasi, bukan sesuatu yang terberi. Babuscio menyatakan dalam hal ini, teatrikal, camp terkait dengan keyakinan diri untuk hidup seperti dalam dunia teater, atau menjadi versus peran, realita dan penampilan. Camp melihat segalanya sebagai sebuah pertunjukan (Babuscio, 1977 : 111). Maka performativitas secara konsisten ditampilkan oleh agen queer untuk menampilkan identitasnya.

\section{Parodi Camp, Kritik dalam sebuah Tiruan}

Parodi Camp selalu menyertakan penyimpangan dalam setiap tindakan peniruan yang dilakukan. Penyimpangan tersebut sekaligus menyertakan aspirasi dari kaum marjinal, dalam hal ini transgender untuk mengkritik 'normalitas' yang berlaku. Dalam hal ini Meyer menyatakan bahwa tanpa proses parodi, agen marjinal tidak akan mempunyai akses terhadap representasi, aparatus yang dikontrol oleh tatanan dominan. Camp, sebagai parodi queer menjadi satu-satunya proses yang dapat memasukkan queer ke dalam representasi 


\section{Jurnal Poetika Vol. IV No. 1, Juli 2016}

untuk memproduksi social visibility. (Meyer, 1994 :9).

Dalam novel Hiding My Candy, pengarang merepresentasikan strategi parodi Camp dalam tiga bentuk. Yang pertama adalah parodi klub sosialita the Savannah League of Uptown White Women (S.L.U.W.W). Klub sosialita yang didirikan oleh tokoh The Doll dengan beberapa temannya itu merupakan klub imitasi terhadap budaya perempuan kulit puth kelas atas di Amerika. Namun, ada penyimpangan dalam peniruan yang dilakukan oleh The Doll. Bukannya berkumpul bersama perempuanperempuan sosialita kulit putih sebenarnya, klub S.L.U.W.W merekrut anggota dari kalangan transgender berkulit hitam dan berwarna. Hal itu merupakan sebuah penyimpangan yang sengaja dimunculkan oleh pengarang untuk menghasilkan ruang kritik terhadap budaya heteronormatif.

Penyimpangan juga tampak dalam kegiatan yang dilakukan oleh klub S.L.U.W.W bentukan The Doll dan kawan-kawannya yang menyalahi pakem dari klub sosialita wanita berkulit putih yang asli. Ketika para sosialita kulit putih biasanya menjadikan pertemuan klub sebagai ajang formal dengan agenda-agenda tertentu yang melibatkan publisitas dan kegiatan amal sebagai dalih dari hedonisme mereka, klub tiruan yang dipimpin oleh The Doll merupakan klub informal. Dalam setiap pertemuannya, The Doll dan rekan-rekannya mengisi waktu dengan memasak atau bergosip saja tanpa embelembel publisitas atau pun kegiatan amal dan lain-lain. Maka penyimpangan-penyimpangan yang memang sengaja dilakukan oleh The Doll dengan klubnya itu sejatinya merupakan sebuah parodi Camp yaitu tiruan yang sekaligus juga menyuguhkan sebuah kritik tersirat dari kaum marjinal terhadap eksklusifitas kaum dominan. Dalam hal ini kaum gay dan transgender mewakili kaum marjinal dan kaum dominan direpresentasikan oleh wanita berkulit putih sosialita kelas atas.

Bentuk parodi Camp yang dimunculkan dalam novel Hiding My Candy berikutnya adalah parodi kontes kecantikan transgender.
Umumnya, kontes kecantikan seperti Miss Universe dan Miss World adalah sebuah privilege yang hanya bisa diikuti dan diselenggarakan oleh masyarakat heteronormatif. Perempuanperempuan 'normal' paling cantik secara fisik merupakan kandidat utama dari kontes tersebut.

Namun, Lady Chablis membuat sebuah ironi dengan menyuguhkan parodi kontes kecantikanserupayanghanyadiperuntukkanbagi kaum transgender, atau yang dalam perspektif heteronormatif kaum yang dianggap sebagai liyan. Apabila dalam budaya heteronormatif, yang menjadi peserta adalah kaum perempuan 'normal', maka kontes kecantikan transgender dikhususkan bagi para kandidat Miss Pageant yang beridentitas transgender male to female atau transvestive. Diceritakan dalam novel, The Doll mengikuti kontes kecantikan khusus transgender yang bertajuk Miss Ches Cabaret, Miss Peachtree Pageant dan Miss Gay World. Ia pun berhasil memenangkan kontes dan membawa pulang gelar The Grand Empress of Savannah.

Kategori penilaian tersebut tidak terlalu berbeda dengan kontes Miss Universe, misalnya, yang mensyaratkan pesertanya untuk mengenakan gaun malam, pakaian nasional, baju renang dan juga adu bakat serta wawancara. Namun, dalam peniruan akan kategori penilaian kontes beauty pageant ini pun terlihat ada unsur penyimpangan atau flaw yang memang sengaja dilakukan oleh kaum transgender. Misalnya, untuk gaun malam yang dikenakan oleh The Doll dalam kontes, ia memodifikasi gaun malam biasa menjadi sebuah kostum yang ia sebut 'sultry' atau menantang. Ia melengkapi penampilannya dengan topi kap berbulu yang ia kenakan secara miring, dan baju yang terbuka di tempat-tempat tertentu seperti di paha. Hal tersebut menjadi flaw, karena dalam kontes Miss Universe misalnya, kontestan adalah sesosok ideal perempuan cantik dengan fisik sempurna dan kostum menawan. Namun, dalam kontes beauty pageant, kontestan bukanlah sosok 'perempuan' ideal itu. Bahkan dengan mempertunjukkan begitu banyak aksesori berbulu, kostum yang begitu 


\section{Jurnal Poetika Vol. IV No. 1, Juli 2016}

menantang dan mencolok, mungkin The Doll akan ditertawakan oleh para pencinta kontes ratu-ratuan. Namun, justru penyimpanganpenyimpangan itu yang diangkat oleh The Doll untuk menunjukkan kritik terhadap produk budaya kaum dominan seperti kontes-kontes kecantikan kelas internasional.

Parodi Camp yang direpresentasikan dalam novel Hiding My Candy selanjutnya adalah penampilan The Doll yang seperti layaknya seorang wanita seutuhnya, tetapi di balik penampilan feminin itu, ia masih mempertahankan alat kelamin laki-lakinya. Ia menyebut dirinya sebagai the Lady with T, atau disingkat Thang, istilah yang ia gunakan untuk menyebut penisnya. Justru di situ lah nyawa parodi Camp berada. Dengan mempertahankan penisnya, The Doll ingin menunjukkan identitas diri yang sesungguhnya. Ia yakin bahwa walaupun secara fisik tubuhnya adalah laki-laki, tetapi ia memiliki jiwa feminin. Parodi Camp yang dilakukannya juga sekaligus mengimplikasikan bahwa sah-sah saja untuk berbeda dari normalitas, karena yang terpenting adalah menjadi dirinya sendiri.

Seperti yang dinyatakan oleh Jack Babuscio, Camp mengemuka dengan semangat ketidaklayakan atau penyimpangan. Ironi penyandingan fisik maskulin dan gestur feminin adalah salah satu strategi Camp yang dilakukan oleh transgender untuk menonjolkan diri. Sebuah ironi muncul dalam ketidaklayakan yang ditampilkan oleh Camp, yang menarik bagi sensibilitas kaum gay, bahwa camp menyajikan penggunaan perbandingan yang konsisten antara maskulinitas/femininitas, muda/tua (umur), jiwa/fisik dan tinggi/rendah (status sosial).(Babuscio, 1977:97).

\section{Ironi dalam Humor Camp, Perspektif Humor untuk Menghadapi Masalah}

Strategi Camp yang direpresentasikan dalam novel Hiding My Candy selanjutnya adalah humor Camp yaitu semangat kaum transgender untuk melihat segala sesuatu dari lensa Camp. Perspektif Camp mengimplikasikan sikap positif untuk selalu mencari sisi humor dalam setiap situasi. Maka, ketika ada persoalan datang, ada kesusahan yang melanda, humor menjadi strategi mereka untuk tetap bertahan. Melihat segala sesuatu dari lensa Camp merupakan upaya kaum transgender untuk menghibur diri mengingat segala pandangan negatif dan diskriminasi dari kaum heteronormatif yang kerap kali menimpa mereka. Newton juga menyatakan bahwa ideologi Camp adalah suatu hal yang bekerja dengan cara meruntuhkan konotasi negatif dan marjinalitas dari praktik peng-other-an oleh masyarakat, melalui sebuah brand spesifik dari humor. Humor Camp adalah 'sistem tawa atas ketidaklayakan posisi seseorang dibanding menangisinya. Jadi, humor tidak menutupinya, tetapi bertransformasi. (Newton, 1997 : 100).

Dalam novel Hiding My Candy, strategi humor Camp direpresentasikan dalam dua bentuk yaitu monolog (stand up comedy) dan situasi-situasi yang menggambarkan laughter in tears atau tawa dalam duka. Dalam setiap pertunjukkan stand up comedy yang dibawakan oleh The Doll, ia selalu mengangkat isuisu tentang transgender yang seakan terlihat seperti mencemooh diri sendiri. Misalnya saja, ia membuat lelucon mengenai 'kotex' dan 'clit' atau klitoris yang tentu tidak dimiliki oleh seorang transgender karena mereka bukanlah perempuan 'normal'. Selain itu, The Doll juga merayakan penderitaan cemoohan dan ejekan yang diterimanya sebagai sesuatu yang positif. Contohnya ketika orang-orang mengejeknya dengan panggilan 'nigger' dan Miss Pee-Wee karena penis yang masih dipertahankannya, ia justru menjadikan panggilan itu sebagai 'nickname'.

Ketika ia terkungkung dalam penjara karena pelanggaran kartu identitas dan tidak boleh mengenakan pakaian perempuan serta berdandan, The Doll tetap berpikiran positif dan mengandalkan kemolekan pipi serta keseksiannya untuk mempertunjukkan identitas transgendernya.

Humor Camp bukan sekedar lelucon tanpa arti. Ada sebuah ironi yang coba diangkat dalam setiap pertunjukkan humor Camp yang 
mempunyai semboyan 'laughter in tears'. Ketika kaum marjinal menjadi korban dari kekangan heteronormatif, sudut pandang humor menjadikan mereka kuat karena mereka mampu menemukan unsur humor dalam setiap duka sehingga mampu menertawakan diri sendiri yang akhirnya bertransformasi sebagai penanda semangat pemberdayaan transgender.

Dalam hal ini, O'Connell menyatakan bahwa humor lebih dari sekedar kegembiraan karena dengan memanfaatkan humor kita dapat mengubah persepsi kognitif secara cepat untuk menjauhkan diri dari ancaman situasi bermasalah, dan melihat permasalahan dari perspektif yang berbeda (dari segi kelucuannya) untuk mengurangi rasa cemas dan tidak berdaya yang seringkali melumpuhkan (O'Connell dalam Martin dan Lefcourt, 1983:147).

\section{Unsur Exaggeration dan Incongruity dalam Strategy of Posing}

Strategi dalam bersikap yang dilebihlebihkan dan juga seringkali mengangkat ketidaklayakan kaum transgender sendiri juga merupakan bentuk kritik terhadap pendiktean tatanan heteronormatif seperti pemapanan konstruksi gender normatif dan eksklusifitas kaum heteroseksual yang serba teratur dan dibatasi. Strategy of posing dilakukan kaum transgender dengan memakai kostum gender yang salah (cross-dressing), gestur feminine dan gaya bicara satire. Ketika masyarakat menuntut laki-laki berkostum maskulin dan sebaliknya perempuan berkostum feminin, kaum transgender bermain-main dalam aspek 'failed seriousness' dan 'being what is not ala Camp dan mengenakan atribut sebaliknya. Dalam novel Hiding My Candy juga diceritakan bahwa The Doll menggunakan lexicon ciptaannya sendiri yang hanya dimengerti oleh sesama kalangan transgender

Gaya berpakaian dan berdandan The Doll yang terlihat terlihat berlebihan mungkin akan tampak aneh di mata orang lain. Kendati demikian, sesungguhnya hal tersebut merupakan perwujudan dari fitur exaggerated costume yang memang merupakan unsur penting dari strategy of posing. Ketika mata kaum heteroseksual memandang takjub penampilan kaum transgender ini dan merasa geli atau bahkan mengejeknya, justru di saat itulah pesan strategi Camp transgender tersampaikan. Tyson menyatakan dalam hal ini, perilaku yang menjadikan sebuah istilah sebagai referensi yang dilekatkan kepada dirinya sendiri merupakan sebuah pergerakan yang kuat, yang seakan juga menyuarakan pikiran bahwa "kami tidak takut untuk terlihat', "kamu tidak berhak mengatakan siapa kami', dan "kami bangga terlahir berbeda" (Tyson, 2006 : 334).

Pernyataan kaum transgender yang menyatakan bahwa mereka tidak takut untuk terlihat dan tidak merasa keberatan untuk terlahir berbeda justru bertransformasi menjadi kekuatan bagi mereka sendiri. Hal itu sekaligus menyatakan bahwa transgender justru menemukan identitas diri pada saat mereka tampil berbeda dari apa yang dinarasikan oleh kaum dominan, dalam hal ini kaum heteroseksual. Di saat mereka terinjak, di saat itu pula mereka justru semakin kuat. Mereka mendefinisikan diri mereka dalam cara dan kode etik mereka sendiri, dari cara berpakaian dan juga cara berdandan.

\section{Strategi Life in Performance sebagai Tantangan terhadap Pendiktean Identitas Gender Normatif}

Bentuk strategi Camp yang terakhir adalah strategi hidup dalam pertunjukkan yang mengimplikasikan kritik terhadap pendiktean terhadap identitas gender. Ketika gender menjadi performatifitas, maka ada berbagai variasi pilihan yang dapat dirayakan seseorang dalam menentukan identitas gendernya. Maka, dalam novel Hiding My Candy, The Doll yang terlahir sebagai laki-laki memilih untuk menunjukkan identitas transgender male to female yang ia rengkuh dan praktikkan secara repetitif dan berkesinambungan lewat performatifitasnya sebagai transgender male-to female dalam kehidupan sehari-hari.

Hal tersebut merupakan perwujudan dari strategi Camp yaitu fitur being in a role playing 


\section{Jurnal Poetika Vol. IV No. 1, Juli 2016}

(hidup dalam pertunjukkan). Fitur pertunjukkan ditonjolkan karena apa yang mereka lakukan dalam keseharian tidak sesuai dengan apa yang dinarasikan oleh masyarakat terhadap diri.

Dunia homoseksual, via drag, menyuarakan bahwa perilaku peran jenis kelamin dapat terlihat dari penampilan luar. Hal itu dapat dimanipulasi sesuka hati. Lebih kompleks lagi drag adalah inversi ganda yang sekaligus menyatakan : meskipun penampakan luar saya terlihat feminin, esensi interior saya adalah maskulin. Namun demikian, dalam situasi yang sama drag juga menyimbolkan inversi berlawanan: penampakan luar (tubuh saya, gender saya) adalah maskulin tetapi esensi dalam diri saya adalah feminin. (Newton, 1999 : 98)

Pernyataan Newton itu menunjukkan bahwa kritik yang termuat dalam strategi hidup dalam pertunjukkan adalah bahwa identitas gender seseorang bukanlah identitas terberi. Ketika drag queen dapatmemodifikasipenampilan wanita hanya dari penampilan luar yang feminin, maka demikian juga identitas gender yang dapat diperoleh dengan upaya performatifitas. Hal ini sekaligus juga menggarisbawahi bahwa sebagai kaum marjinal, mereka mempunyai hak untuk menampilkan identitasnya dalam role playing yang mereka upayakan dalam keseharian mereka.

\section{Kebertahanan Transgender sebagai Muara Akhir Strategi Camp}

Pengarang merepresentasikan strategi Camp dalam novelnya dengan agenda besar yakni tercapainya kebertahanan transgender dalam menghadapi kekangan masyarakat heteronormatif. Tujuan kebertahanan transgender itu ia representasikan dalam novel Hiding My Candy dengan menghadirkan tokoh The Doll yang sukses sebagai transgender entertainer dan juga artis film. Diskriminasi dan pelabelan negatif serta ancaman kekerasan fisik yang seringkali membatasi transgender dalam kehidupannya adalah latar belakang pengarang untuk menampilkan serangkaian strategi untuk kebertahanan transgender tersebut.
Selanjutnya, strategi Camp direpresentasikan pengarang sebagai media kritik terhadap tatanan heteronormatif yang selama ini seringkali mengabaikan dan bahkan me-liyan-kan posisi kaum transgender. Pengarang merepresentasikan strategi Camp sebagai serangkaian cara yang bisa dipraktikkan oleh kaum transgender untuk membuktikan bahwa mereka ada (social visibility), mempunyai identitas dan cara hidup sendiri (wacana normalitas alternatif) serta mampu berprestasi (transgender empowerment), sama seperti orang lain dalam masyarakat. Unsur-unsur itulah yang menurut pengarang dapat menjamin kebertahanan kaum transgender dalam kekangan heteronormativitas.

Visibilitas sosial diupayakan melalui pertunjukkan strategy of posing (kostum crossdressing, gestur feminin dan gaya bicara satire). Kaum transgender mampu menunjukkan diri di hadapan masyarakat dengan menjadi sosok yang mempraktikkan cross-dressing dengan mencolok, mempertunjukkan gestur yang bukan merupakan harapan masyarakat dan menyuarakan aspirasinya melalui gaya bicara satire. Unsur-unsur Camp seperti failed seriousness, exaggeration dan incongruity merupakan hal-hal yang diangkat dalam strategi untuk social visibility ini.

Sementara itu, aspek wacana normalitas alternatif dalam kebertahanan transgender diupayakan melalui pertunjukkan strategi parodi identitas gender yang bertransformasi menjadi apropriasi gender, parodi kontes kecantikan khusus transgender, parodi pembentukan klub sosialita khusus transgender kulit berwarna dan penggunaan lexicon ala transgender.

Menghadapi kekakuan normalitas heteronormatif terhadap kaum transgender, pengarang menawarkan wacana normalitas alternatif ala transgender yang lebih mengakomodasi eskpresi diri kaum transgender dalam bentuk apropriasi gender dan parodi budaya kaum dominan (kontes kecantikan khusus transgender, pembentukan klub sosialita dan lexicon khusus transgender). Wacana normalitas alternatif ini tidak dimaksudkan 


\section{Jurnal Poetika Vol. IV No. 1, Juli 2016}

untuk memutarbalikkan normalitas yang sudah ada, melainkan sebagai pilihan yang diharapkan mampu memberikan ruang gerak yang lebih leluasa kepada kaum marjinal, khususnya transgender. Penyajian ruang normalitas alternatif ini ditujukan agar kaum transgender mampu bertahan hidup dan menyalurkan potensinya di berbagai bidang tanpa bayangbayang diskriminasi.

Aspek kebertahanan transgender yang terakhir adalah pemberdayaan transgender. Dalam hal ini pengarang menyuarakan pesan bahwa kaum transgender yang telah mengaplikasikan strategi humor Camp dalam kehidupannya akan mampu menjadi figur yang mempunyai power karena mereka telah mampu mentransformasikan penderitaan menjadi kekuatan. Mereka telah menjadi subjek dan seorang subjek tentu lebih leluasa menyalurkan eskpresi diri sehingga mampu berprestasi dalam berbagai bidang. Contohnya saja, tokoh The Doll yang mampu menjuarai berbagai kontes kecantikan ala transgender seperti Miss Peachtree Pageant, gelar The Grand Empress of Savannah dan juga menjadi artis film ternama di Amerika. Maka, pengarang menjadikan prestasi-prestasi The Doll tersebut sebagai motivasi untuk sesama kaum transgender bahwa mereka pun dapat menyalurkan bakat dan kemampuan diri untuk hal-hal positif.

\section{Kesimpulan}

Dari pembahasan yang telah dipaparkan sebelumnya dapat ditarik kesimpulan mengenai bentuk-bentuk strategi Camp dan tujuan pengarang merepresentasikan fitur strategi Camp dalam novel Hiding My Candy. Bentuk bentuk strategi Camp yang direpresentasikan Lady Chablis dalam novel Hiding My Candy meliputi strategi parodi Camp, strategi humor Camp, strategi bersikap (kostum, gestur dan gaya bicara) serta strategi hidup dalam pertunjukkan (life in performance). Selain untuk tujuan visibilitas sosial transgender, serangkaian strategi Camp direpresentasikan pengarang dalam novelnya untuk menyuarakan kritik terhadap tatanan heteronormativitas.
Tujuan pengarang merepresentasikan strategi Campdalam novel HidingMy Candy adalah untuk mencapai kebertahanan transgender (transgender survival). Kebertahanan transgender itu menurut pengarang dapat dicapai melalui aspek-aspek social visibility, normalitas alternatif dan transgender empowerment. Artinya, seorang transgender dapat dikatakan bertahan dalam masyarakat ketika ia telah mampu menampilkan diri di hadapan kaum normatif, dengan menonjolkan cara hidup dan normalitas ala mereka sendiri serta berprestasi dalam berbagai bidang serta mempunyai kedudukan yang sama seperti individu lain dalam masyarakat.

\section{Daftar Pustaka}

Aryanto dan Triawan, Ridho. 2008. Jadi, Kau Take Meras Bersalah? Studi Kasus Diskriminasi dan Kekerasan terhadap LGBTI. Jakarta: Citra Grafika.

Babuscio, Jack. 1977. Camp and the Gay Sensibility In Gays and Films. edited by Richard Dyer. London: British Film Institute.

Booth, Mark. 1983. Camp. London: Quartet.

Chablis, Lady. 1997. Hiding My Candy. Los Angeles: Pocket Books

Cleto, Fabio. 1999. Queering the Camp.In Camp: Queer Aesthetic and the Performing Subjects. edited by Fabio Cleto. Michigan: The University of Michigan Press.

Green, Eli R and Peterson, Erick N. 2005. LGBTQI Terminology: the Instructional Material Section. Riverside: UC Riverside.

Isherwood, Christopher. 1999. The World in the Evening. In Camp: Queer Aesthetics and the Performing Subject, edited by Fabio Cleto, 49-52. Ann Arbor, MI: The University of Michigan Press.

Katz, J. 1976. Gay American History: Lesbians and Gay Men in the USA. New York :Crowell Company.

Martin, R.A. dan Lefcourt, H.M. 1984. Situational Responses Questionnaire: Quantitative Measure of Sense of Humor. Journal of Personality and Social Psychology. 47, 1, 145-155. 
Jurnal Poetika Vol. IV No. 1, Juli 2016

Meyer, Moe. 1994. The Politics and Poetics of Camp. NewYork: Routledge.

Tyson, Lois. 2006. Critical Theory Today: A User Friendly Guide. New York : Routledge.

Udasmoro, Wening. 2015. Apropriasi Gender dalam Sastra, Media dan Wacana Seharihari. Yogyakarta: Prodi Sastra Prancis FIB UGM.

Wilson, Erin Catherine.2008. Male-to-Female Transgender Youth : Stigma, Discrimination and the Relationship to HIV. Berkeley : University of Carolina.

\section{Pustaka Laman}

Chapell, Bill. 2015. Supreme Court Declares SameSex Marriage Legal in All 50 States. diakses dari laman www.npr.org/sections/ thetwoway/2015/06/ pada 15 Agustus 2015 pukul 14.45 WIB.

Mosbergen, Dominique. 2013. Transgender Discrimination in USA. diakses dari laman www.huffpost.com/us/ entry/35/486041 